\title{
Surface characteristics and biocompatibility of cranioplasty titanium implants following different surface treatments
}

Dol:

10.1016/j.dental.2018.01.016

\section{Document Version}

Accepted author manuscript

Link to publication record in Manchester Research Explorer

Citation for published version (APA):

Hatamleh, M. M., Wu, X., Alnazzawi, A., Watson, J., \& Watts, D. (2018). Surface characteristics and biocompatibility of cranioplasty titanium implants following different surface treatments. Dental Materials, 34(4), 676-683. https://doi.org/10.1016/j.dental.2018.01.016

\section{Published in:}

Dental Materials

\section{Citing this paper}

Please note that where the full-text provided on Manchester Research Explorer is the Author Accepted Manuscript or Proof version this may differ from the final Published version. If citing, it is advised that you check and use the publisher's definitive version.

\section{General rights}

Copyright and moral rights for the publications made accessible in the Research Explorer are retained by the authors and/or other copyright owners and it is a condition of accessing publications that users recognise and abide by the legal requirements associated with these rights.

\section{Takedown policy}

If you believe that this document breaches copyright please refer to the University of Manchester's Takedown Procedures [http://man.ac.uk/04Y6Bo] or contact uml.scholarlycommunications@manchester.ac.uk providing relevant details, so we can investigate your claim.

\section{OPEN ACCESS}




\title{
Surface characteristics and Biocompatibility of cranioplasty titanium implants following different surface treatments
}

Muhanad M. Hatamleh, BSc, MPhil, MSc, Dip, PhD

Author for correspondence

Oral and Maxillofacial Department, King's College Hospital, London; SE9 5RS, UK

E-mail: muhanad.hatamleh@gmail.com

Xiaohong Wu, BDS, MSc, $\mathrm{PhD}$

Chongqing Key Laboratory of Oral Diseases and Biomedical Sciences

Chongqing Municipal Key Laboratory of Oral Biomedical Engineering of Higher Education

No. 426 Songshibei Road, Yubei district, Chongqing 401147, China

E-mail: hiwxh@hotmail.com

\begin{abstract}
Ahmad Alnazzawi, DDS, MSc, $\mathrm{PhD}$
Department of Substitutive Dental Science,

Faculty of Dentistry,

Taibah University, Madinah,

Saudi Arabia.

Email: alnazzawi@gmail.com
\end{abstract}

Jason Watson, BMed Sc, MIMPT

Consultant, Healthcare Scientist,

Maxillofacial Department, Queens Medical Centre Campus

Nottingham University Hospital Trust ; Nottingham, NG7 2UH, UK

Email: jason.watson@nuh.nhs.uk

David Watts PhD, FADM

University of Manchester

School of Medical Sciences and Photon Science Institute

JR Moore Building, Oxford Road

Manchester, M13 9PL, UK

david.watts@manchester.ac.uk 


\section{Surface characteristics and Biocompatibility of cranioplasty titanium implants} following different surface treatments

\section{Abstract}

Introduction and aims: Surface and mechanical properties of titanium alloys are integral for their use in restoring bone defects of skull and face regions. These properties are affected by the method of constructing and surface treatment of the titanium implant. This study aimed to investigate the effects of titanium finishing protocols on the surface morphology, hardness and biocompatibility of TiAl6V4. Materials and Methods: Square shaped TiAl6V4 specimens (ASTM F68) (10x10x0.5mm) were divided into seven groups of different surface treatments $(\mathrm{n}=10)$. The treatments included mechanical polishing, sandblasting with $\mathrm{AL}_{2} \mathrm{O}_{3}$ (50 um), immersion in different acids, and /or electro-chemical anodization. Weight loss \%; 3D microroughness; Knoop micro-hardness, and osteoblast cell attachment and proliferation (after 3 days) were determined for each specimen. Data was analysed using one way ANOVA and Dunett T3 post-hoc tests, and $t$-test $(\mathrm{p}<0.05)$. Results: Weight loss $\%$ was in the range of $1.70-5.60$ as mechanical polishing produced the highest weight loss, followed by sandblasting, and combined protocol of mechanical polishing and acid treatment $(\mathrm{p}<0.05)$. Micro-roughness values (um) were in the range of 2.81-16.68. It was the highest for control specimens $(p<0.05)$, and smoothest surfaces after combined mechanical polishing and acid treatment; or after electrochemical treatment $(\mathrm{p}<0.05)$. Micro-hardness values $(\mathrm{MPa})$ ranged $170.90-442.15$ as sandblasting with/without acid treatment caused statically significantly the highest values $(p<0.05)$ while control and mechanically polished specimens had the lowest values $(p<0.05)$. All treatments produced equally biocompatible surfaces $(\mathrm{p}>0.05)$ after $1 \mathrm{hr}$ or 3 days. Furthermore, osteoblast cell proliferation statistically significantly increased after 3 days among each surface treatment $(\mathrm{p}<0.05)$. Significance: Different finishing treatments have variable effect on cranioplasty titanium surface loss, micro-roughness and micro-hardness but constant improved biocompatibility effect. Electro-chemical treatment caused less material loss and produced 
biocompatible smoothest surface of comparable hardness; hence it can be suitable for cranioplasty titanium surface finishing.

\section{Introduction}

Metallic biomaterials are used to construct medical devices that replaces hard tissue such as artificial hip joints, bone plates, and dental implants [1 2]. In the past 20 years, the number of intra- and extra-oral implants has increased reaching over one million implantations per year, majorly intra-oral dental implants [3]. Pure titanium and Ti6Al4V are the most commonly used alloys [3-6]. Mainly, because of their excellent combination of biocompatibility, mechanical and electrochemical properties in harsh bodily environments [ll $\left.4 \begin{array}{ll}1 & 7\end{array}\right]$. Patient-specific extra-oral titanium implants (PSI) are increasingly used in reconstructing missing bones of the head and neck secondary to trauma or ablative surgery, thus restoring normal continuity of hard tissues, providing support and protection and restoring aesthetics of overlying soft tissues [8-11]. The PSI's include cranioplasty or skull plates [12-14], orbital floor implants [15-17], and mandibular tumour resection and reconstruction [18-23].

Success of titanium implant depends on effective biomaterial-tissue interaction [24], which is affected by the implant surface composition, hydrophilicity, and morphology including microgeometry and roughness [ $\left[\begin{array}{lll}3 & 25 & 26\end{array}\right]$. After implantation, the surface is conditioned by tissue fluids [26] which modulate cellular activity in the surrounding tissue [25 26]. Titanium surfaces have shown excellent biocompatibility and direct apposition of bone, resulting in cellular attachment and implant fixation [15]. There is considerable variation among customised titanium cranioplasty and jaw implants with respect to design as well as surface treatment [24 27-29]. The surface treatments encompasses wide range of methodologies such as machining, acid etching, electro-polishing, anodic oxidation, sand blasting or plasma-spraying [3 29-33]. However, they serve three major effects; protective effect (i.e. corrosion resistance; wear); decorative effective (i.e. colour); and functional effect (i.e. biocompatibility). While titanium oxide layer can form 
naturally through reacting with oxygen; however controlled oxide layer can be formed by means of chemical; thermal (i.e. heating up to $400 \mathrm{C}$ ); or eletro-chemical oxidation known as anodizing [33]. The development of new surfaces can improve the overall performance of titanium implants, particularly in regard to the acceptance of the device by the body, the healing time after implantation and the long term integrity and stability of the biomaterial/body interface [6].

Therefore the aim of the current work is to investigate the effect of titanium finishing protocols on the surface morphology, hardness and biocompatibility of TiAl6V4. Our null hypothesis indicates that titanium surface will not be affected by the surface finish protocols. 


\section{Materials and Methods}

2.1 Specimen preparation and surface finishing: Seventy square shaped titanium specimens (ASTM F68) $(10 \times 10 \times 0.5 \mathrm{~mm})$ were prepared (TiAL6V4; Titanium International; Birmingham, UK). The specimens were divided into seven groups $(n=10)$ of different surface treatments. Group 1 acted as control. Group 2 specimens were mechanically polished using wheel polish plus pumice. Each sample was polished for 10 seconds following clockwise rotational movement to cover all area. Slight pressure was applied during polishing. Group 3 specimens were immersed in fresh acid (Nitric acid 70\%) for 20 hours. Group 4 specimens were sandblasted with aluminium oxide particles (50 um) at 3-4 bars pressure for 10 seconds. Group 5 specimens were treated using a combination of two protocols; mechanical polishing and then acid immersion as described earlier. Group 6 specimens were treated using a combination of sandblasting followed by acid immersion as described earlier. And group 7 specimens were acid etched in solution of nitric (69\%) and hydrofluoric (48\%) acids for 10 min then electrochemically treated in solution of orthophosphoric (85\%) and sulphuric acid (98\%) at $12 \mathrm{mV}$. Specimens of each group were placed in ultrasonic cleaning bath for 10 minutes for cleaning before commencing the measurements. Four measurements were obtained for each specimen; weight to the nearest 0.000001 gram; three dimensional Micro-roughness (3D microRoughness); Knoop Micro-hardness; and osteoblasts cell attachment and proliferation tests.

2.2 Weight measurements: They were performed at eight to the nearest 0.000001 gram. Specimens were weighed before (W0) and after (W1) surface treatment and weight percentage loss $(\mathrm{WL} \%)$ was calculated as follows: $\mathrm{WL} \%=((\mathrm{W} 0-\mathrm{W} 1) / \mathrm{W} 0) * 100)$

2.3 3D Surface roughness: A non-contact surface profilometry (Talysurf CLI 1000, Taylor Hobson precision) was used. Bi-directional scanning ( $\mathrm{X}$ and $\mathrm{Y}$ axes) was performed at scanning speed of $500 \mu \mathrm{m} / \mathrm{sec}$. The $3 \mathrm{D}$ roughness values (height measurements) evaluated were (ISO 25178) Sq (root mean square height of the surface) and Sku. 
2.4 Knoop micro-hardness: Micro-hardness tester (FM-700, Future tech Corp, Kwasaki-Ku, Japan) was used and a load of $300 \mathrm{gm}$ and dwell time $15 \mathrm{sec}$ were employed in having three indentations per specimens. Average value was calculated.

2.5 Cell culture and MTT test: Titanium sheets $(n=5)$ were washed using ultrasonic irrigation for $30 \mathrm{~min}$. Then the samples were washed with distilled water and dried. High-pressure steam sterilization was used for disinfection. Osteoblasts (1.5X104) and 1ml DMEM medium (invitrogen) supplemented with 10\% heat inactivated fetal bovine serum (invitrogen) and $100 \mathrm{U} / \mathrm{ml}$ each of penicillin /streptomycin were added on the titanium surface in each well. They were placed in $37{ }^{\circ} \mathrm{C} 5 \% \mathrm{CO}_{2}$ saturated water vapour carbon dioxide incubator for 1 hour or 3 days for further tests. At the end of the culture period, the titanium sheets were transferred to new 24-well plate with $1 \mathrm{ml}$ FCS-free DMEM medium and $20 \mu 1 \mathrm{MTT}(5 \mathrm{mg} / \mathrm{ml})$ dye on each titanium sheet. A blank well (containing only the same concentration and volume of the DMEM medium and MTT dye) was set. The cultures were incubated for 4 hours. DMSO (150ul) was added in each well. Liquid (100ul) was taken from each well into a 96-well plate. The optical density (OD) values were measured with enzyme-linked detector, and the detection wave length was $570 \mathrm{~nm}$.

2.6 Statistical analysis : Data was analysed using one way ANOVA and Dunett T3 post-hoc tests, and $t$-test (SPSS, version 20, Il, USA) at significance level of $\mathrm{P}<0.05$. Levens test of homogeneity was performed and Dunett T3 test was used as equal variances could not be assumed in running post-hoc tests $(\mathrm{P}<0.05)$.

\section{Results}

Results and statistical significances are presented in Table 1 and Figures (3-6). There were statistically significant effects of surface finishing protocols on the properties tested $(\mathrm{p}<0.05)$. Surface images of the specimens under different treatments were captured using Optical 
microscope at $\mathrm{x} 40$ (Figure 1). Also, SEM images were captured at various magnifications (500 and 3000) (Figure 2).

Percentage of weight loss was in the range of 1.70-5.60. Mechanical polishing caused the highest weight loss, followed by sandblasting, then combined mechanical polishing and acid treatment $(\mathrm{p}<0.05)$.

Micro-roughness Sq values (um) were in the range of 2.81-16.68. It was the highest for control specimens. The surfaces were less rough $(\mathrm{p}<0.05)$ when mechanically polished or acid treated only as the Sq values were 6.96 and 5.77 um respectively. Statistically significantly smoothest surfaces $(\mathrm{p}<0.05)$ were achieved after following combined protocol of mechanically polishing and acid treatment; or after electro-chemical treatment and Sq values were reduced by at least a factor of 5 and were 3.27 and 2.81 um respectively. Micro-roughness kurtosis of the surfaces $(\mathrm{SKu})$ were in acceptable range of 1.87-3.03.

Knoop micro-hardness values ranged 170.90-442.15. Sandblasting combined with/without acid treatment caused highest values $(\mathrm{p}<0.05)$. On the other hand, control specimens and specimens mechanically polished only had the lowest values $(\mathrm{p}<0.05)$.

Biocompatibility test of osteoblast cell attachment showed that all surface treatments produced equally biocompatible surface ( $\mathrm{p}>0.05)$ after $1 \mathrm{hr}$ or 3 days.

Osteoblast bone growth ranged $0.128-0.132$, and $0.357-0.400$ after $1 \mathrm{hr}$ and 3 days respectively. Osteoblast cell proliferation increased after 3 days among each surface treatment protocol $(\mathrm{p}<0.05)$. 


\section{Discussion}

This study showed that surface and mechanical properties of TiAl6V4 are affected by the method of titanium implant surface treatment, hence we rejected the null hypothesis. For cranioplasty implants, it is preferable that finishing does not affect the plate thickness as the plate is thin (i.e. $0.25-0.7 \mathrm{~mm})$. Mechanical polishing caused the highest weight loss $(5.60 \%)$. It can be due to the nature of polishing that includes the use of polishing lathe along micro-particle of polishing agent (i.e. pumice). However, the non-contact protocols of acid immersion caused the least loss (1.70-1.90\%). Interestingly, the weight loss of the contact-based protocols was reduced from 5.60 and 3.88 to 3.67 and 2.19 when samples were immersed in acid after mechanical polishing and sandblasting respectively. The difference was in the range of 1.69-1.93 $\%$ which is similar to that reported for including acid only treatment. It is important to maintain adequate thickness of the titanium plate so that the implant can serve protection function. It could be viable to start with thicker plate to accommodate for lost thickness during plate processing. However, thick titanium plates are difficult to shape and form.

After treating the surface, specimens' roughness was measured using non-contact 3D profilometry. Roughness plays an important role in determining how a real object will interact with its environment. It is often a good predictor of the performance of a mechanical component as in orthopaedic applications. On the other hand, roughness may promote adhesion as in dental applications. The roughness Sq value represent the root mean square height of the surface and it is the most commonly reported value. Titanium sheet in its original state had the highest roughness value (14.53) which was not affected by sandblasting $(\mathrm{p}>0.05)$. However, the roughness was reduced, almost by half when specimens were either polished or acid treated only $(\mathrm{p}<0.05)$. Interestingly, surface roughness was optimally reduced by a factor ranging $4.50-5$ when specimens were polished and acid treated; or when they were electro-chemically treated. They were the smoothest. The Sku values (kurtosis) which represents the sharpness of a surface, 
and expresses the pointing of the height distribution were all in the range of 1.87-3.03. These are often used for evaluation of surface gloss and luster. If the $\mathrm{Sku}=3$, then it is normally distributed while height distribution is considered spiked when the value is greater than 3 and surface is squashed when value is less than 3 . While all values were accepted for the specimens, having the specimens polished and then acid treated produced the surface with "normal" kurtosis when compared to the control group (Sku were 3.03 and 1.88 respectively) $(\mathrm{p}<0.05)$

Micro-hardness is an important parameter that could be used to define the mechanical properties in relation to its microstructure, especially when a material is subjected to complex load patterns as in dental applications or orthopaedics [34]. Static indentation test was employed in testing the titanium specimens. It involved forcing a pyramid into the surface of the titanium being tested, and the relationship of load to the area or depth of indentation is the measure of Knoop hardness. Hence, the hardness is evaluated by the amount of permanent deformation, in terms of depth of the indentation or by measuring the area. As the test material becomes softer, the depth of penetration becomes greater. Likewise, the projected area increases as the test material becomes softer. The micro-hardness values ranged 176.18 to 442.15 for control and sandblasting groups respectively. Sandblasting with/without acid immersion exhibited a significantly high surface hardness and was significantly the highest value among all other surface treatments. The value was more than double of control group. This is in harmony with other study that nitrided titanium alloy samples which resulted in an increasingly nodular surface and significantly higher mean roughness values [35]. This could confirm improved wear behaviour of treated titanium alloy surfaces which would be of significant effect in medical use like orthopaedics [36]. This can be explained by the presence controlled surface roughness by particle beads. These beads left micro-voids and irregularities within the surface which acted as nucleation sites for cracks.

Osteogenesis, induced by osteoblastic cells, is characterized by a sequence of events, involving cell attachment, cell proliferation and followed by the expression of osteoblast phenotype [29 
32]. In the present study showed that all discs, independent of the surface roughness, allowed cell attachment, and cell proliferation. Within each time interval, cell attachment was not affected by surface roughness and ranged from $0.130-0.133$ and $0.366-0.400$ after $1 \mathrm{hr}$ and 3 days respectively which is in harmony with the literature [28 29]. Hence it can be concluded that all surface treatment of titanium implant result in biocompatible layer titanium oxide layer. Evaluations of in vitro biocompatibility of titanium using osteoblast cell culture have also indicated that rough surfaces would favour the development of some cell activities. Cell attachment increases on rough surfaces [30], however, this was not prevalent in the current study because of the small difference in Sq values (roughness) obtained by this study. This is in harmony with other study that showed osteonectin, osteopontin, and osteocalcin gene expression (at week 1) were not affected by the different surface treatments [27].

It was noted that nitric acid treatment following an ageing surface finishing (i.e. mechanical polishing or sandblasting) affected the surface properties for mechanical polishing groups only in terms of roughness and hardness $(\mathrm{p}<0.05)$. This could be due to metal ion dissolution behaviour in a simulated biological fluid. Ti6A14V in general is most sensitive to treatment in nitric acid by exhibiting a decrease in surface oxide thickness, an increase in Al concentration within the oxide, and an increase in dissolution of constituent metals into serum containing culture medium [37]. Previous work demonstrated that the different surface treatments alter the metal ion release kinetics and surface composition of the TiA16V4 alloy [38 39]. A study found that the release of $\mathrm{Al}$ ions was about 0.84 um for the ageing treatment and about 5.55 um for the passivation treatment after 7 days [38]. The kinetics of the metal ion dissolution, especially for Al, could then explain the differences in cell behaviour, which were observed only in long-term in vitro study [27]. However, this was not documented in the current study as it was only for 3 days. 
Titanium surface roughness influences the cell behaviour [25-27]. We used 3D profilometry to examine the surface properties of the treated TiAl6V4 surfaces. The range difference in roughness $(\mathrm{Sq})$ between the smoothest and roughest samples of the different passivated and the aged surface treatments was observed at a small scale 2.81-16.68. Therefore, at the cell level, the roughness could be considered similar between samples and could explain the similar behaviour in osteoblasts after $1 \mathrm{hr}$ or 3 days. Regardless, biocompatibility tests such as those performed in this study can only quantify particular aspects of cell behaviour. The cell reaction to an implant is however a very complex situation and can only be partially understood using standard biological assays. Lastly, the risk of microbial contamination of the titanium skull plate during surgery is very minimal when compared to dental implants as the skull implants is sterilized at high temperature and packaged. And it is only opened in sterile environment during surgery.

\section{Conclusions:}

Within the limitations of this study, the following conclusions were drawn:

1. Mechanical polishing, acid etching and sandblasting affect titanium micro-roughness and micro-hardness. However, cell attachment and proliferation remained unaffected at after hr or 3 days.

2. Electro-chemical treatment of TiAl6V4 caused less material loss to produce an implant of comparable hardness and smoothest surface; hence it can be suitable for cranioplasty titanium surface finishing. 


\section{References}

1. Niinomi M. Metallic biomaterials. J Artif Organs 2008;11:105-10.

2. Wang K. The use of titanium for medical applications in the USA. Materials Science and Engineering A213 1996;I34- I37.

3. Le Guehennec L, Soueidan A, Layrolle P, Amouriq Y. Surface treatments of titanium dental implants for rapid osseointegration. Dent Mater 2007;23:844-54.

4. Niinomi M. Mechanical properties of biomedical titanium alloys. Materials Science and Engineering A243 1998; 231-236.

5. Buser D, Schenk R, Steinemann S, Fiorellini J, Fox C, H. S. Influence of surface characteristics on bone integration of titanium implants. A histomorphometric study in miniature pigs. J Biomed Mater Res 1991;25:889-902.

6. D. M. Brunette, P. Tengvall, M. Textor, P. Thomsen, Titanium in Medicine. 2001: Springer-Verlag Berlin Heidelberg GmbH.

7. Rack HJ, Qazi JI. Titanium alloys for biomedical applications. Materials Science and Engineering C 26 2006;1269 - 1277.

8. Parthasarathy J. 3D modeling, custom implants and its future perspectives in craniofacial surgery. Ann Maxillofac Surg 2014;4:9-18.

9. Eufinger H, Wehmoller M, Machtens E, Heuser L, Harders A, Kruse D. Reconstruction of craniofacial bone defects with individual alloplastic implants based on CAD/CAMmanipulated CT-data. J Craniomaxillofac Surg 1995;23:175-81.

10. Derand P, Rannar LE, Hirsch JM. Imaging, virtual planning, design, and production of patient-specific implants and clinical validation in craniomaxillofacial surgery.

Craniomaxillofac Trauma Reconstr 2012;5:137-44.

11. Sing SL, An J, Yeong WY, Wiria FE. Laser and electron-beam powder-bed additive manufacturing of metallic implants: A review on processes, materials and designs. J Orthop Res 2016;34:369-85.

12. Day RE, Guy DT, Kop AM, Morrison DA. The Royal Perth Hospital method for the design and manufacture of titanium cranioplasty plates. Br J Oral Maxillofac Surg 2012;50:376-7.

13. Sharma SD, Lim B, Bentley RP. Preservation of the temporalis muscle during cranioplasty. Br J Oral Maxillofac Surg 2012;50:e36-7.

14. Wiggins A, Austerberry R, Morrison D, Ho KM, Honeybul S. Cranioplasty with custommade titanium plates--14 years experience. Neurosurgery 2013;72:248-56; discussion 256. 
15. Gerbino G, Zavattero E, Zenga F, Bianchi FA, Garzino-Demo P, Berrone S. Primary and secondary reconstruction of complex craniofacial defects using polyetheretherketone custom-made implants. J Craniomaxillofac Surg 2015;43:1356-63.

16. Kozakiewicz M, Elgalal M, Walkowiak B, Stefanczyk L. Technical concept of patientspecific, ultrahigh molecular weight polyethylene orbital wall implant. J Craniomaxillofac Surg 2013;41:282-90.

17. Brie J, Chartier T, Chaput C, Delage C, Pradeau B, Caire F, et al. A new custom made bioceramic implant for the repair of large and complex craniofacial bone defects. J Craniomaxillofac Surg 2013;41:403-7.

18. Foley BD, Thayer WP, Honeybrook A, McKenna S, Press S. Mandibular reconstruction using computer-aided design and computer-aided manufacturing: an analysis of surgical results. J Oral Maxillofac Surg 2013;71:e111-9.

19. Ciocca L, Mazzoni S, Fantini M, Persiani F, Marchetti C, Scotti R. CAD/CAM guided secondary mandibular reconstruction of a discontinuity defect after ablative cancer surgery. J Craniomaxillofac Surg 2012;40:e511-5.

20. Watson J, Hatamleh M, Alwahadni A, Srinivasan D. Correction of facial and mandibular asymmetry using a computer aided design/computer aided manufacturing prefabricated titanium implant. J Craniofac Surg 2014;25:1099-101.

21. Hou JS, Chen M, Pan CB, Tao Q, Wang JG, Wang C, et al. Immediate reconstruction of bilateral mandible defects: management based on computer-aided design/computer-aided manufacturing rapid prototyping technology in combination with vascularized fibular osteomyocutaneous flap. J Oral Maxillofac Surg 2011;69:1792-7.

22. Hirsch DL, Garfein ES, Christensen AM, Weimer KA, Saddeh PB, Levine JP. Use of computer-aided design and computer-aided manufacturing to produce orthognathically ideal surgical outcomes: a paradigm shift in head and neck reconstruction. J Oral Maxillofac Surg 2009;67:2115-22.

23. Hatamleh MM, Bhamrah G, Ryba F, Mack G, Huppa C. Simultaneous Computer-Aided Design/Computer-Aided Manufacture Bimaxillary Orthognathic Surgery and Mandibular Reconstruction Using Selective-Laser Sintered Titanium Implant. J Craniofac Surg 2016;27:1810-1814.

24. Keller JC, Draughn RA, Wightman JP, Dougherty WJ, Meletiou SD. Characterization of sterilized CP titanium implant surfaces. Int J Oral Maxillofac Implants 1990;5:360-7. 
25. Marinucci L, Balloni S, Becchetti E, Belcastro S, Guerra M, Calvitti M, et al. Effect of titanium surface roughness on human osteoblast proliferation and gene expression in vitro. Int J Oral Maxillofac Implants 2006;21:719-25.

26. Martin JY, Schwartz Z, Hummert TW, Schraub DM, Simpson J, Lankford J, Jr., et al. Effect of titanium surface roughness on proliferation, differentiation, and protein synthesis of human osteoblast-like cells (MG63). J Biomed Mater Res 1995;29:389-401.

27. $\mathrm{Ku} \mathrm{CH}$, Pioletti DP, Browne M, Gregson PJ. Effect of different Ti-6Al-4V surface treatments on osteoblasts behaviour. Biomaterials 2002;23:1447-54.

28. Kumar A, Bhat V, Balakrishnan M, Hashem M, Vellappally S, Al Kheraif AA, et al. Bioactivity And Surface Characteristics Of Titanium Implants Following Various Surface Treatments: An In Vitro Study. J Oral Implantol 2014;

29. Rosa AL, Beloti MM. Effect of cpTi surface roughness on human bone marrow cell attachment, proliferation, and differentiation. Braz Dent J 2003;14:16-21.

30. Anselme K, Linez P, Bigerelle M, Le Maguer D, Le Maguer A, Hardouin P, et al. The relative influence of the topography and chemistry of TiAl6V4 surfaces on osteoblastic cell behaviour. Biomaterials 2000;21:1567-77.

31. Ask M, Lausmaa J, B K. Preparation and surface spectroscopic characterization of oxide "lms on Ti6Al4V. Appl Surf Sci 1988;35:283-301.

32. Anselme K. Osteoblast adhesion on biomaterials. Biomaterials 2000;21:667-81.

33. Puippe JC. Surface treatment of titanium implants European Cells and Materials 2003;5:32-33.

34. Sanosh KP, Balakrishnan A, Francis L, Kim TN. Vickers and Knoop Micro-hardness Behavior of Coarse-and Ultra fine-grained Titanium. J. Mater. Sci. Technol 2010;26:904907.

35. Venugopalan R, George MA, Weimer JJ, Lucas LC. Surface topography, corrosion and microhardness of nitrogen-diffusion-hardened titanium alloy. Biomaterials 1999;20:1709-16.

36. Davidson JA, Mishra AK, Kovacs P, Poggie RA. New surface-hardened, low-modulus, corrosion-resistant Ti-13Nb-13Zr alloy for total hip arthroplasty. Biomed Mater Eng 1994;4:231-43.

37. B. W. Callen, R. N. S. Sodhi, K. Griffiths. Examination of clinical surface preparations on titanium and Ti6Al4V by X-ray photoelectron spectroscopy and nuclear reaction analysis. Progress in Surface Science 1995;50:269-279. 
38. Browne M, Gregson PJ, West RH. Characterization of titanium alloy implant surfaces with improved dissolution resistance. J Mater Sci Mater Med 1996;7:323-9.

39. Bowers KT, Keller JC, Randolph BA, Wick DG, Michaels CM. Optimization of surface micromorphology for enhanced osteoblast responses in vitro. Int J Oral Maxillofac Implants 1992;7:302-10. 


\section{List of legends- Tables}

Table 1: Mean (sd) values of Weight loss \%, Micro-Roughness, Micro-hardness and biocompatibility of the different surface treatments

\section{List of legends- Figures}

Figure 1: Different surface topographies of Ti64 finished with different procedures. Control (A), mechanical (B), acid (C), sandblasting (D), polish and acid (E) and sandblasting and acid (F).

Figure 2: SEM images of the specimen surfaces after different surface treatments and at four different magnifications (500 and 3000)

Figure 3: Weight loss $\%$ of the TiAl6V4 specimens of different surface treatments

Figure 4: Sq of the 3D micro-roughness of the TiAl6V4 specimens of different surface treatments

Figure 5: Knoop micro-hardness $(300 \mathrm{gm}, 15 \mathrm{sec})$ of the TiAl6V4 specimens of different surface treatments

Figure 6: Biocompatibility test of the TiAl6V4 specimens of different surface treatments 

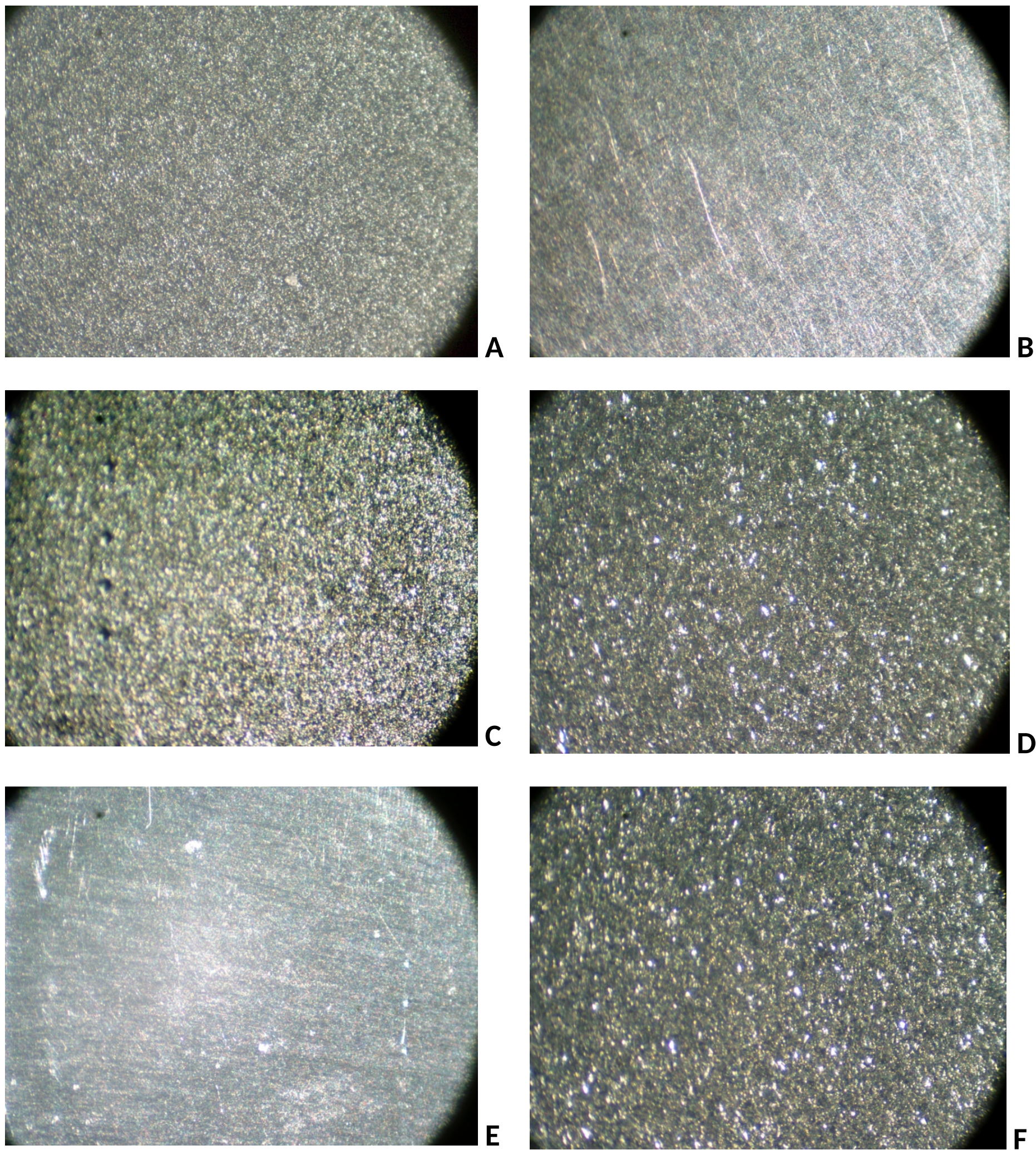

Figure 1: Different surface topographies of Ti64 finished with different procedures. Control (A), mechanical (B), acid (C), sandblasting (D), polish and acid (E) and sandblasting and acid (F). 


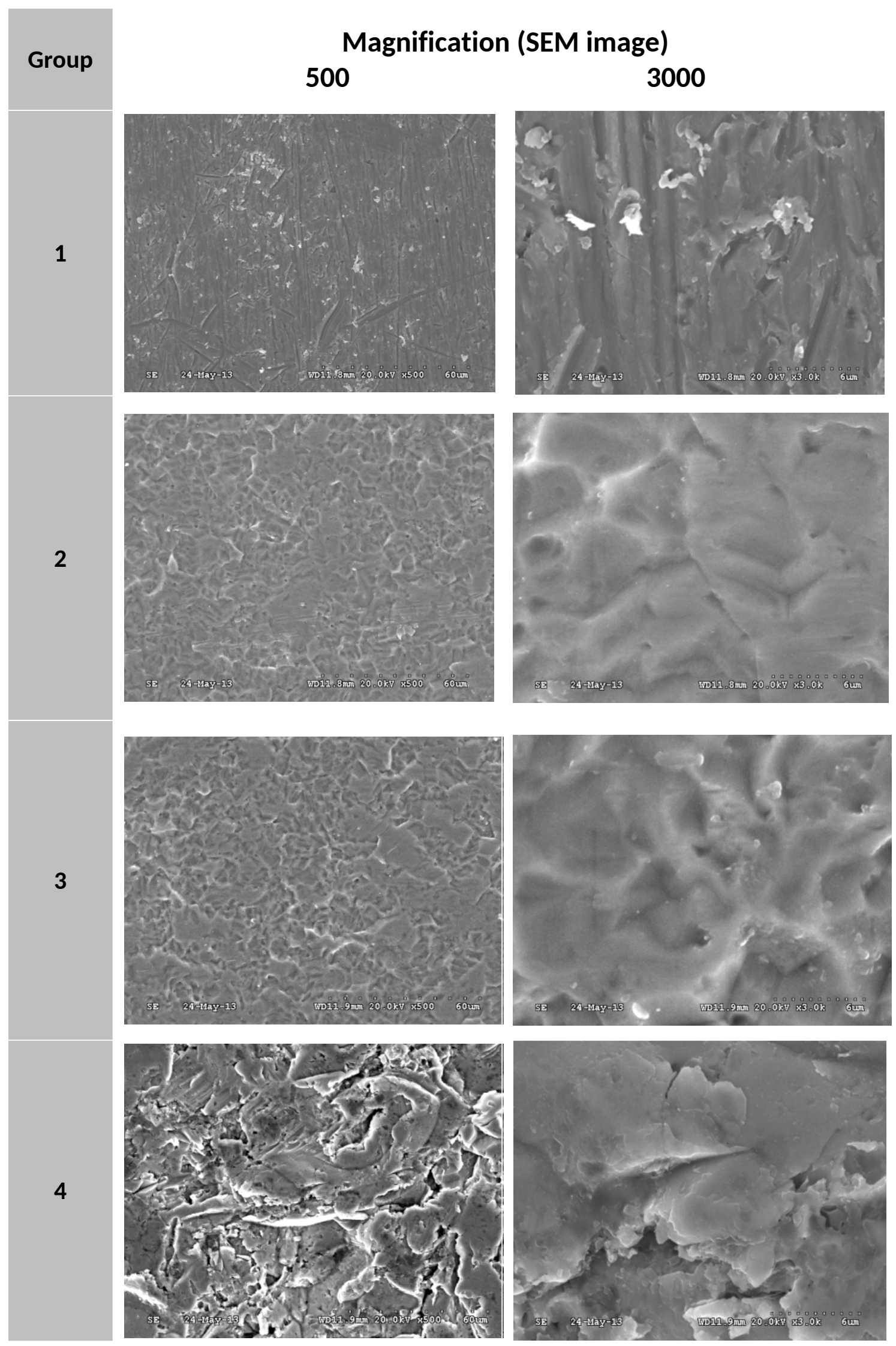



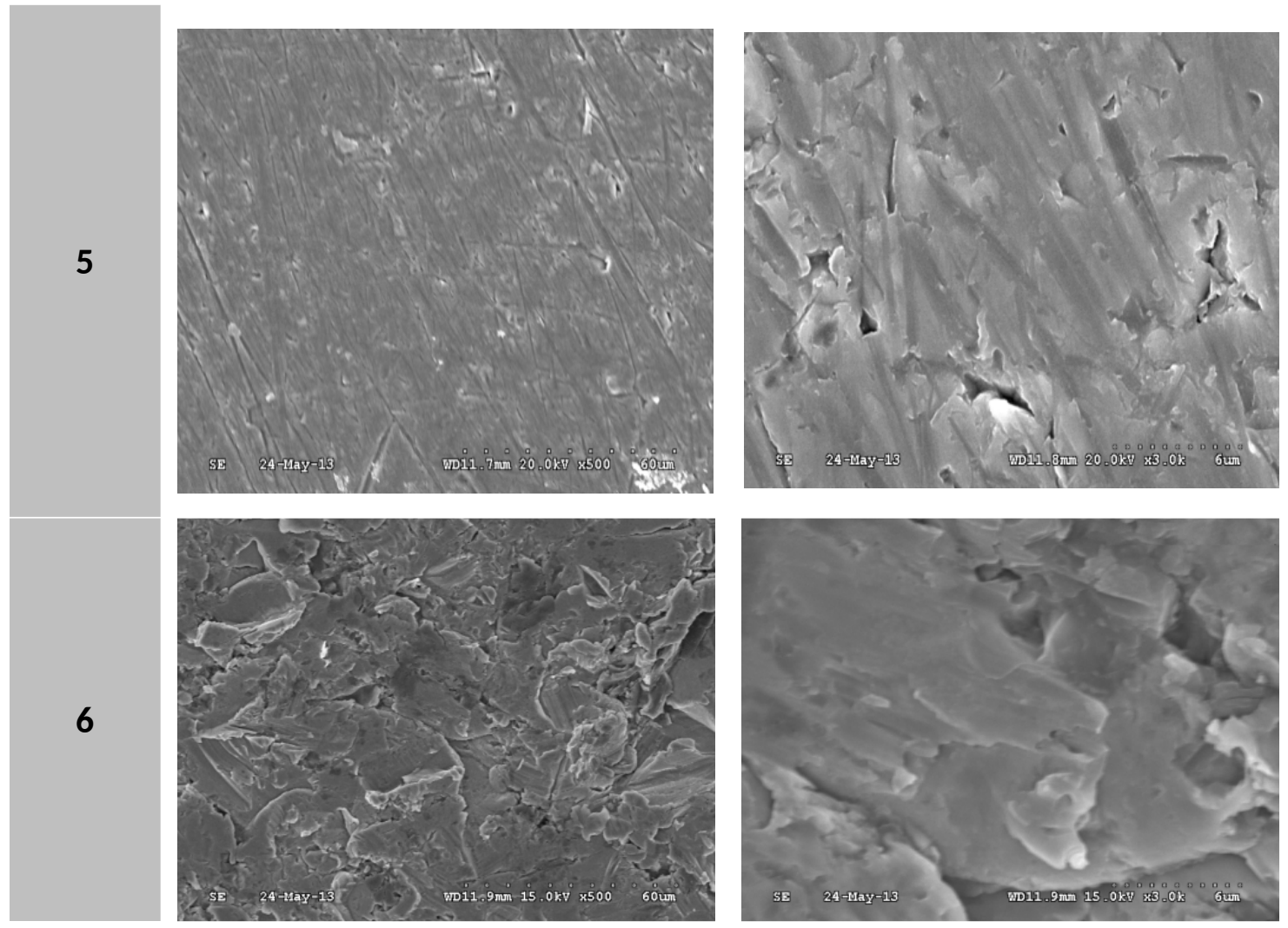
Figure 2: SEM images of the specimen surfaces after different surface treatments and at four different magnifications (500 and 3000)

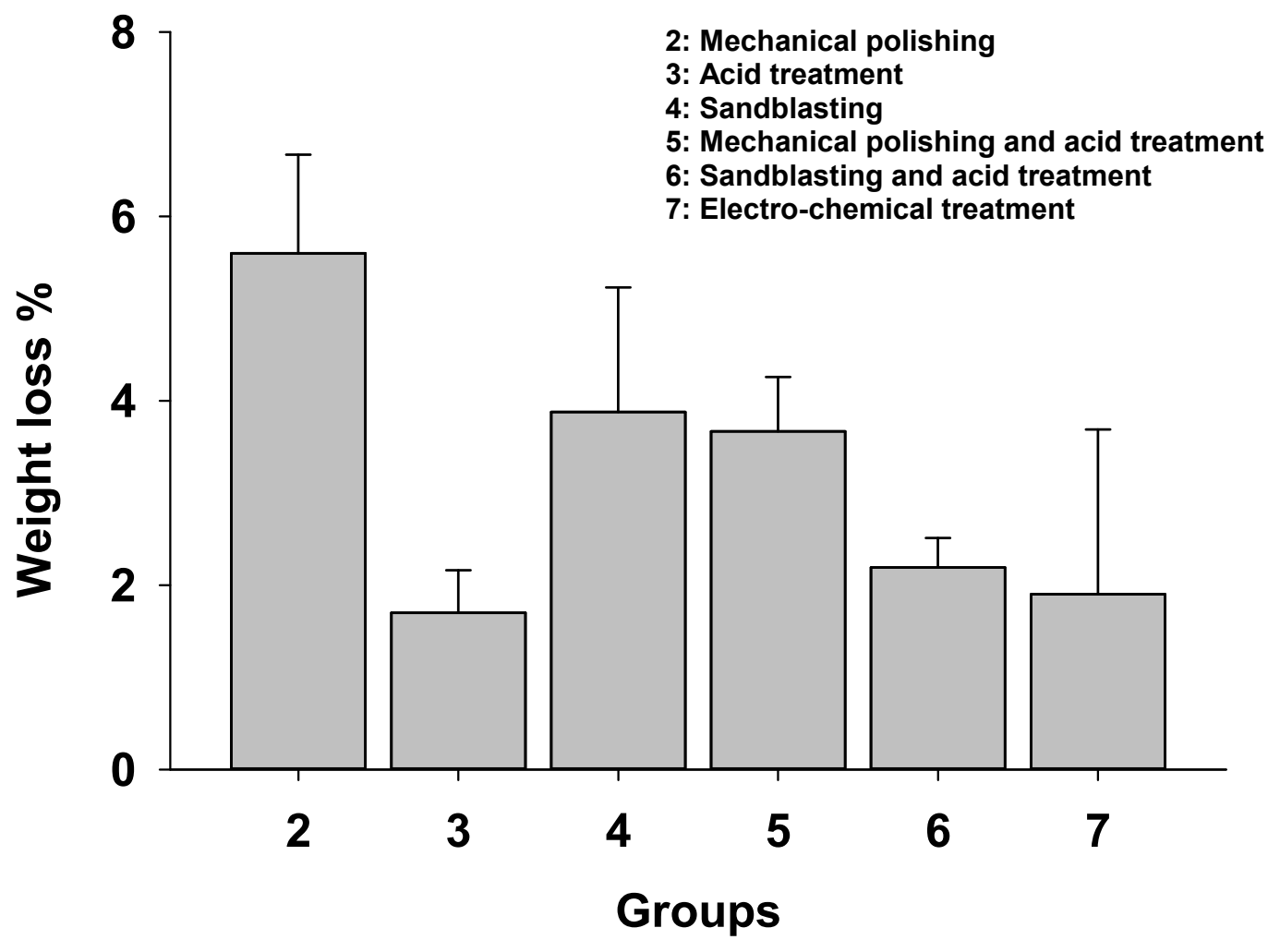

Figure 3: Weight loss \% of the TiAl6V4 specimens of different surface treatments 


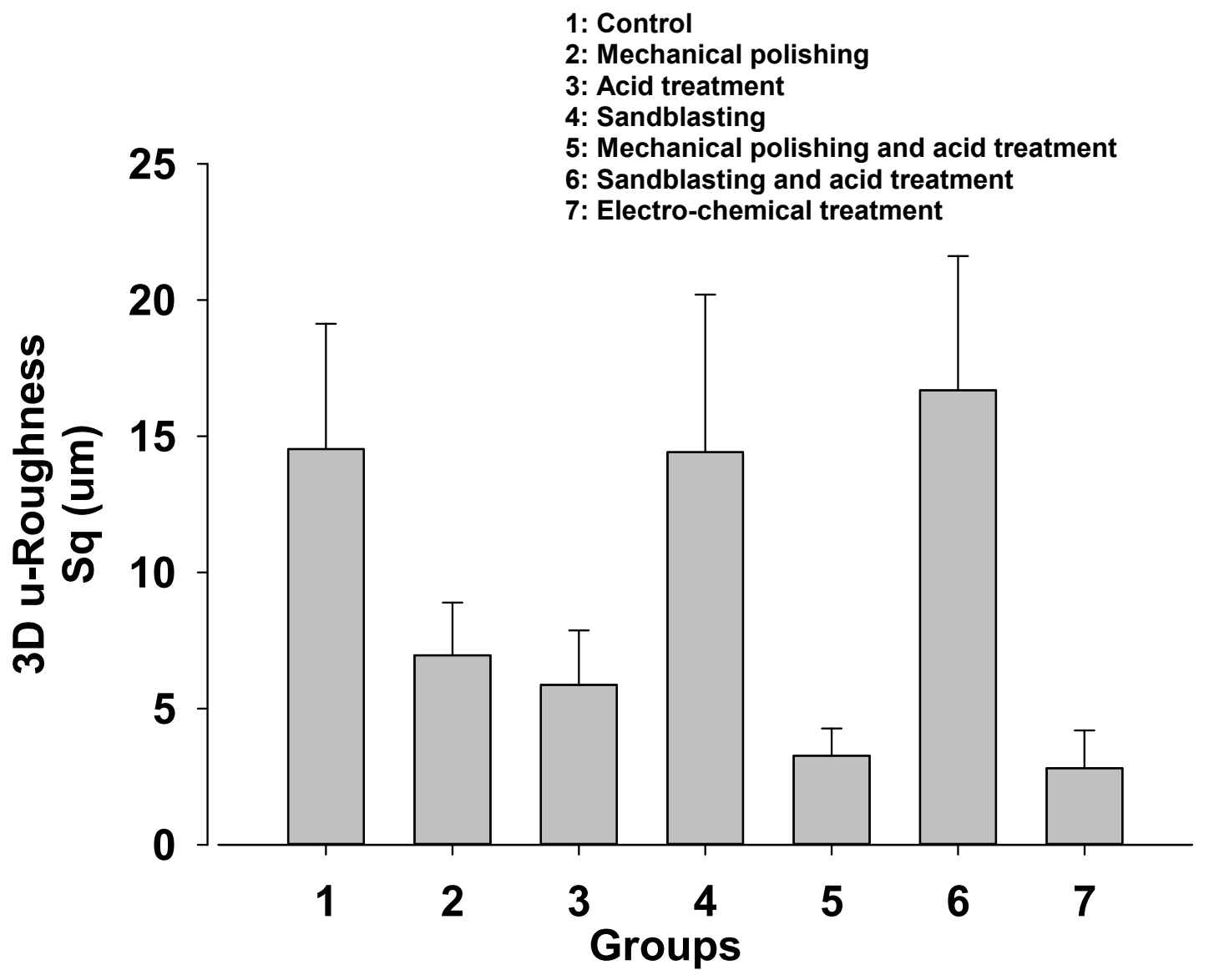

Figure 4: Sq of the 3D micro-roughness of the TiAl6V4 specimens of different surface treatments 


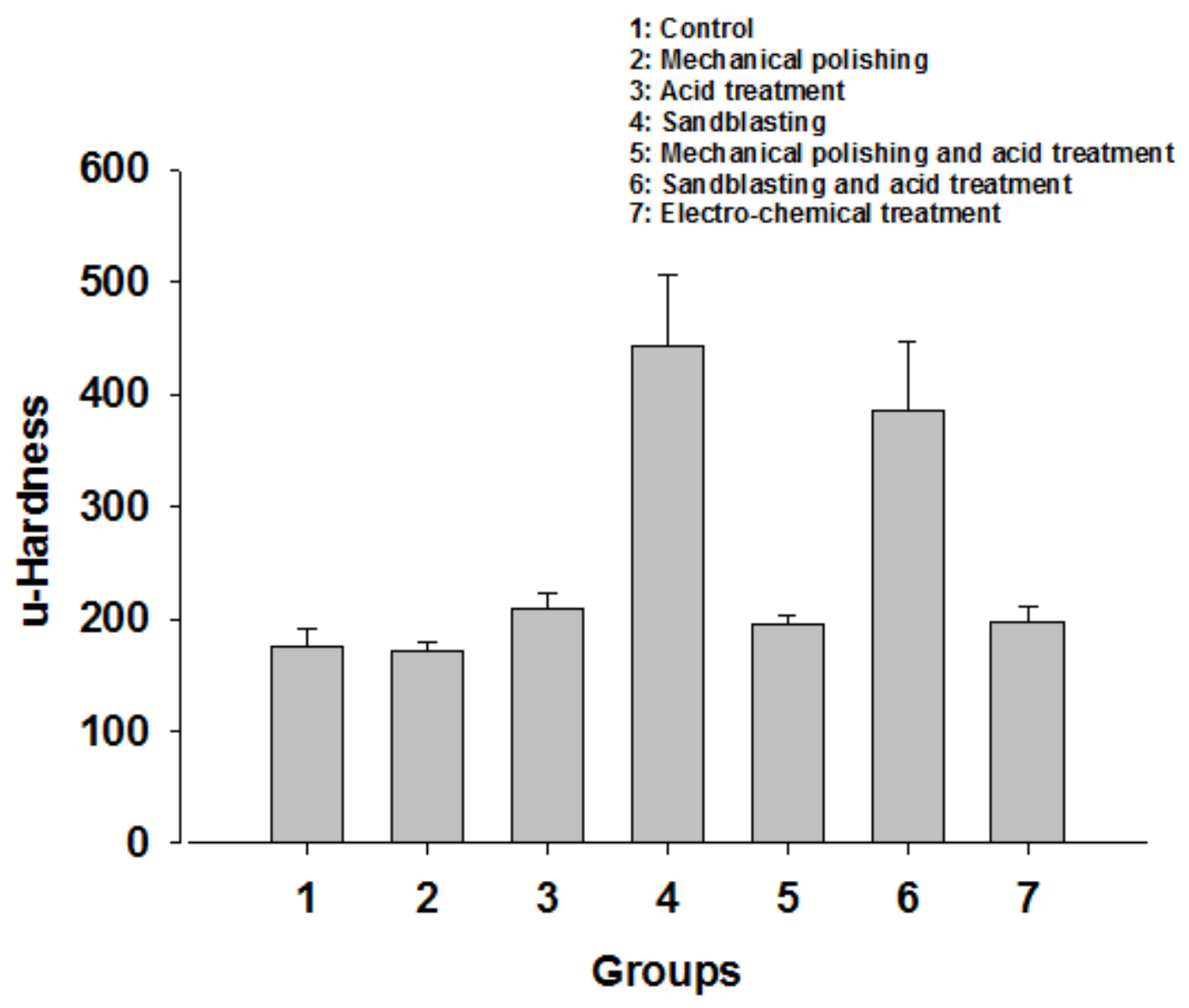

Figure 5: Knoop micro-hardness (300 gm, $15 \mathrm{sec})$ of the TiAl6V4 specimens of different surface treatments 


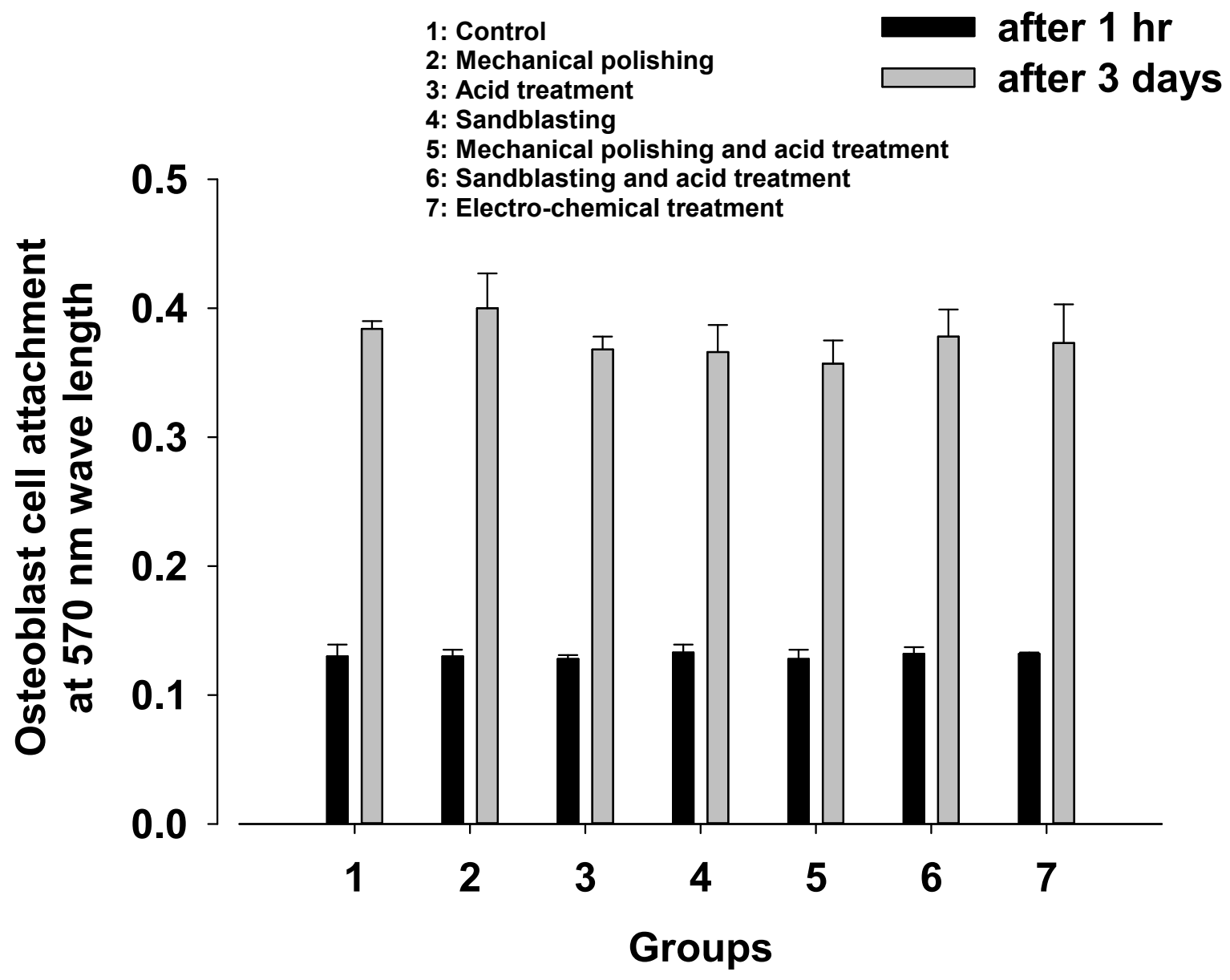

Figure 6: Biocompatibility test of the TiAl6V4 specimens of different surface treatments 